\title{
Pengembangan instrumen keterampilan dasar konseling Pada mahasiswa calon konselor
}

\author{
Tri Anjar \\ FKIP Universitas Muhammadiyah Metro \\ Email: trianjar69@yahoo.com
}

(Diterima: 29-Maret-2017; di revisi: 04-Mei-2017; dipublikasikan: 29-Juni-2017)

\begin{abstract}
This research aims to develop basic skills counseling instruments which refer to various counseling theories and techniques that will be used to measure the ability of students in individual counseling practicum courses. Subjects were students Prodi BK sixth semester, the University of Muhammadiyah Metro totaling 44 students. Retrieving data using Likert scale model of the scale of basic counseling skills. The analysis revealed the acquisition of scores of each indicator that is the understanding of theoretical concepts and techniques of counseling the ideal score is 616 , while perolehen a total score of 382 , the indicator Already using theoretical approach and counseling techniques ideal score is 264 , while the acquisition of the total score is 166, then the accuracy of selecting an approach to counseling theories and techniques, the ideal score is 264 and earned a total score of 144, and the indicators used counseling theories and techniques correctly, obtained a total score of 383 out of a score of 616 is ideal. Conclusion of research is the basis of student counseling keterampilaan Prodi BK sixth semester at the University of Muhammadiyah Metro, is still relatively moderate. Recommendations advice pembeajaran quality needs to be improved and need to be arranged individual counseling practicum guides more specific and easier to use prospective student counselor.
\end{abstract}

Keywords: Instrument; Individual Counseling; Counselors Candidates.

\begin{abstract}
Penelitian ini bertujuan untuk mengembangkan instrumen keterampilan dasar konseling yang merujuk kepada berbagai teori dan teknik konseling yang akan digunakan untuk mengukur kemampuan mahasiswa pada mata kuliah praktikum konseling individual. Subyek penelitian adalah mahasiswa Prodi BK semester VI, Universitas Muhammadiyah Metro yang berjumlah 44 mahasiswa. Pengambilan data menggunakan model skala Likert yakni skala keterampilan dasar konseling. Hasil analisis menunjukkan perolehan skor masing-masing indikator yakni pemahaman konsep teori dan teknik konseling skor ideal yaitu 616, sedangkan perolehen skor total 382, pada indikator Sudah menggunakan pendekatan teori dan teknik konseling skor ideal adalah 264 sedangkan perolehan skor total yaitu 166, kemudian ketepatan memilih suatu pendekatan teori dan teknik konseling, skor ideal yaitu 264 dan perolehan skor total sebesar 144, dan pada indikator menggunakan teori dan teknik konseling secara benar, diperoleh total skor sebesar 383 dari skor ideal 616. Kesimpulan penelitian adalah keterampilan dasar konseling mahasiswa Prodi BK pada semester VI di Universitas Muhammadiyah Metro, masih tergolong sedang. Rekomendasi saran perlu ditingkatkan kualitas pembeajaran dan perlu disusun panduan praktikum konseling individual yang lebih spesifik dan mudah digunakan mahasiswa calon konselor.
\end{abstract}

Kata Kunci: Instrument=;, Konseling Individu; Calon Konselor.

Copyright (C) 2017 Universitas Negeri Makassar.. This is an open access article under the CC BYNC-ND license (http://creativecommons.org/licenses/by-nc-nd/4.0/). 


\section{PENDAHULUAN}

Pelayanan konseling adalah salah satu bentuk hubungan yang sifatnya membantu, mengupayakan individu atau konseli agar mampu mengembangkan potensi secara mandiri sehingga dapat mengambil keputusan dan pilihan untuk mewujudkan kehidupan yang efektif, produktif serta bahagia. Tujuan konseling bisa tercapai apabila konselor memiliki berbagai kompetensi yang dibutuhkan untuk membantu konseli, sehingga cakap dan terampil

Secara jelas telah tertuang dalam Undang-Undang Nomor 20 Tahun 2003 tentang Sistem Pendidikan Nasional Pasal 1 Butir 6 menegaskan bahwa konselor adalah pendidik, sebagaimana juga guru, dosen, pamong belajar, widyaswara, tutor, instruktur dan fasilitator. Karena konselor adalah pendidik maka konseling adalah pendidikan, dan pelayanan konseling adalah pelayanan pendidikan (Prayitno, 2009).

Sedangkan pelayanan konseling adalah pekerjaan yang profesional, yang berarti pekerjaan atau kegiatan yang dilakukan oleh seseorang dan menjadi sumber penghasilan kehidupan yang memerlukan keahlian, kemahiran/kecakapan yang memenuhi standar mutu atau norma tertentu serta memerlukan pendidikan profesi. (UU No.14/2005 Pasal 1 Butir 4).

Pada kenyataannya di semua satuan pendidikan tingkat SMP dan SMA sederajad khususnya di kota Metro, belum ada guru BK yang lulusan pendidikan profesi konselor, bahkan masih banyak terdapat guru BK yang berlatar belakang pendidikan bukan sarjana bimbingan dan konseling. Hal ini mengindikasikan bahwa belum terpenuhinya persyaratan keprofesionalan sebagai petugas yang profesional di bidang konseling yakni belum terpenuhinya keahlian, kemahiran, atau kecakapan yang memenuhi standar mutu atau norma tertentu serta memerlukan pendidikan profesi (UU No.14 Tahun 2005).

Selain itu dalam penanganan masalah siswa melalui layanan konseling individual, ada kecenderungan guru BK hanya memberikan nasehat pada siswa untuk semua masalah. Hal ini mengindikasikan bahwa belum dikuasainya keterampilan dasar konseling oleh guru BK yaitu belum dipahami teori-teori dan/atau teknikteknik dalam konseling sehingga berakibat pada ketidakmampuan guru BK dalam menerapkan teori dan teknik konseling saat membantu mengentaskan masalah siswa, yang berakibat penanganan masalah tidak tuntas. Jika hal itu dibiarkan terus berlangsung, bisa berdampak negatif terhadap profesi itu sendiri, konseli/siswa yang dilayanai, dan persepsi masyarakat. Bahkan yang lebih menghkawatirkan yakni terjadinya malapraktik konseling.

Untuk mengatasi masalah tersebut, maka perlu dipersiapkan tenaga konselor sekolah atau guru bimbingan dan konseling yang handal dan profesional dalam membantu siswa menyelesaikan permasalahan yang dihadapi. Sebagaimana telah dijelaskan dalam Permendiknas Nomor 28 Tahun 2007, bahwa guru BK/Konselor sekolah adalah guru yang memenuhi persyaratan yang diperlukan sebagai tenaga profesional, antara lain dipenuhinya syarat standar kualifikasi akademik yaitu seorang guru BK harus lulusan sarjana bimbingan dan konseling serta lulus pendidikan profesi konselor.

Konseling merupakan salah satu bentuk hubungan yang sifatnya membantu, yaitu konselor membantu mengupayakan orang lain/konseli agar mampu mengembangkan potensi yang dimiliki dan memandirikan konseli dalam pengambilan keputusan dan pilihan untuk mewujudkan kehidupannya secara efektif dalam kesehariannya, produktif, dan bahagia. Secara lebih luas, Rogers (dikutip dari Namora,2011) mengartikan konseling sebagai hubungan membantu di mana salah satu pihak (konselor) bertujuan meningkatkan kemampuan dan fungsi mental pihak lain (konseli), agar dapat menghadapi persoalan konflik yang sedang dihadapi konseli. Oleh karenanya pelayanan konseling diarahkan untuk membantu pengembangan individu dalam setting sekolah dan masyarakat luas, maka harus diselenggarakan oleh tenaga ahli yang profesional (Depdiknas, 2004).

Konseling adalah pekerjaan yang profesional, oleh sebab itu harus dilakukan oleh orang yang memiliki keahlian dibidang konseling dan tidak boleh dilakukan oleh sembarangan orang. Seorang pemegang suatu profesi diwajibkan menguasai sepenuhnya secara terintegrasi komponen kompetensi sesuai profesinya. Komponen kompetensi dalam profesi konseling meliputi; (a) Keintelektualan, (b) Kompetensi yang dipelajari, (c) Objek praktis spesifik, (d) Motivasi altruistik serta, (e) Komunikasi dan organisasi profesi (Prayitno, 2009).

Tujuan konseling bisa tercapai apabila konselor memiliki berbagai kompetensi yang 
dibutuhkan untuk membantu konseli. Kompetensi (competence) yang harus dimiliki konselor mencakup aspek fisik, intelektual, emosional, sosial dan moral (M. Surya, 2009). Kompetensi ini sangat penting bagi seorang konselor, karena konseli datang pada konselor adalah untuk belajar dan mengembangkan kompetensi yang dibutuhkan untuk mencapai hidup yang lebih efektif dan bahagia. Peran seorang konselor adalah mengajarkan kompetensi itu kepada konseli, sehingga makin banyak kompetensi yang dimiliki konselor, maka akan semakin besar kemungkinan konselor dapat membantu konseli. Begitu juga guru BK/Konselor sekolah yang bertugas memberikan pelayanan konseling di sekolah, haruslah guru BK yang kompeten dan profesional di bidang konseling, sehingga dapat membantu siswa dalam pengembangan diri secara optimal sesuai dengan tugas perkembangannya.

Tugas dan kewajiban guru BK/Konselor sekolah adalah membantu pengembangan diri siswa yang mencakup aspek kehidupan pribadi, kehidupan sosial, belajar, karir, keluarga dan kehidupan keberagamaan. Selain itu seorang guru BK/Konselor seharusnya memenuhi standard kualifikasi akademik dan kompetensi konselor yang telah dijelaskan dalam Permendiknas Nomor 28 Tahun 2007 Pasal 1 ayat (1) menyatakan bahwa untuk dapat diangkat sebagai konselor,seseorang wajib memenuhi standard kualifikasi akademik dan kompetensi konselor yang berlaku secara nasional.

Sosok utuh kompetensi konselor mencakup kompetensi akademik dan profesional sebagai satu keutuhan. Kompetensi akademik merupakan landasan ilmiah dari kiat pelaksanaan pelayanan profesional bimbingan dan konseling. Sedangkan kompetensi akademik merupakan landasan bagi pengembangan kompetensi profesional, yang meliputi: (1) memahami secara mendalam konseli yang dilayani, (2) menguasai landasan dan kerangka teoretik bimbingan dan konseling,(3) menyelenggarakan pelayanan bimbingan dan konseling yang memandirikan, dan (4) mengembangkan pribadi dan profesionalitas konselor secara berkelanjutan (Prayitno, 2009).

Untuk memenuhi berbagai kompetensi tersebut memerlukan proses yang cukup panjang. Hal tersebut dapat dimulai dari pembelajaran di perguruan tinggi dengan mempersiapkan mahasiswa program studi bimbingan dan konseling atau calon konselor dengan membekali berbagai pengetahuan, penguasaan konsep teori dan praktik konseling. Penguasaan konsep menurut (Arikunto, 2008) merupakan kemampuan menyerap arti dari materi suatu bahan yang dipelajari. Dengan demikian penguasaan bukan hanya sekedar mengingat mengenai apa yang pernah dipelajari tetapi menguasai, yakni melibatkan berbagai proses kegiatan mental sehingga lebih bersifat dinamis. Untuk menguasai keterampilan maka bukan hanya melibatkan mental, namun juga kegiatan fisik secara bersama-sama atau biasa disebut psikomotor.

Pelayanan pada dasarnya adalah suatu tindakan yang sifat dan arahnya menuju kepada kondisi lebih baik, yang membahagiakan bagi pihak yang dilayani. Dengan kata lain, orang yang sedang dilayani memiliki prospek untuk menjadi lebih baik dan bahagia (Prayitno, 2009). Sedangkan konseling merupakan suatu proses bantuan dari konselor kepada klien/konseli yang didasarkan pada teori dan teknik-teknik yang dikemukakan oleh para ahli bidang konseling. Dimana teori tersebut dirumuskan berdasarkan pengalaman praktik terhadap klien-klien yang telah dikonselingi maupun melalui penelitian yang dilaksanakan selama bertahun-tahun (Taufik, 2009).

Dengan demikian pelayanan konseling hendaknya tertuju secara langsung pada berkembangnya kehidupan yang efektif pada konseli, yang membahagiakan dengan bersumber dasar pada konseptualisasi individu konseli, arahan praktis dan panduan praktik konseling.

Untuk menghindari malapraktik konseling, maka penting sekali bagi calon konselor memahami konsep teori dan teknik konseling sebagai acuan mahasiswa saat praktik konseling, sehingga mahasiswa calon konselor memiliki berbagai keterampilan yang dibutuhkan khususnya dalam pelayanan konseling individual yang akan berguna untuk membantu mengentaskan permasalahan konseli/siswa ketika menjadi guru BK/konselor sekolah nanti. Keterampilan dasar dalam konseling dimulai dari pemahaman konsep teori dan teknik konseling secara benar dan berlatih melalukan praktik konseling secara sungguh-sungguh pada mata kuliah praktikum konseling individu. Dengan demikian diharapkan mahasiswa calon konselor akan lebih terbantu dalam mempersiapkan dirinya menjadi konselor yang cakap dan terampil.

Terampil atau tidaknya konselor saat pelayanan konseling dapat dilihat dari salah satu indikator yakni pendekatan yang digunakan saat 
proses konseling, apakah pragmatik, dogmatik, sinkretik, eklektik atau mempribadi (Prayitno, 2009). Diharapkan mahasiswa calon konselor dapat menguasai secara baik semua teori atau pendekatan konseling. Secara umum pendekatan konseling terbagi menjadi tiga yaitu pendekatan directif, pendekatan non-directif dan pendekatan eklektik. Namun pendekatan umum tersebut secara lebih jauh telah dikembangkan oleh para ahli konseling menjadi 10 pendekatan khusus. Prayitno (2009), menjelaskan secara singkat dari 10 teori atau pendekatan itu sebagai berikut :

1. Konseling Psikoanalisis Klasik yang dikembangkan oleh Sigmun Freud, hendak membawa hal-hal yang tidak disadari oleh subyek yang dilayani ke dalam kesadarannya, dalam rangka meyag selama ini ia gagal mengatasinya.

2. Konseling Ego yang dikembangkan oleh Alder,Jung dan Fromm. Pendekatan ini hendak membangun identitas ego sehingga fungsi ego subyek yang dilayani menjadi kuat.

3. Konseling Psikologi Idividual oleh Alder, yang hendak membantu subyek yang dilayani mengubah konsep tentang dirinya dan mengoreksi persepsi yang salah tentang lingkungannya, serta mengembangkan tujuantujuan baru yang hendak dicapai melalui tingkah laku yang baru.

4. Konseling Analisis Transaksional yang dikembangkan Erick Berne, yang hendak memperkokoh peran dan fungsi ego state adult (dewasa) secara optimal subjek yang dilayani.

5. Konseling Self (Rogers), yang hendak membantu subjek yang dilayani memiliki kedirian (self) yang lebih matang untuk mampu mewujudkan diri sendiri (self actualization).

6. Konseling Gestalt (Perls), yang hendak mendorong pengembangan perilaku subjek yang dilayani menurut prinsip-prinsip Gestalt.

7. Konseling Behavioral (Skinner), yang hendak mendorong pengembangan perilaku subjek yang dilayani menurut prinsip-prinsip belajar dan pembiasaan.

8. Konseling Realitas (Glasser), yang hendak mendorong pengembangan perilaku subjek yang dilayani menurut pilar $3 \mathrm{R}$ : right, responsibility, dan reality.

9. Konseling Rasional-Emotif (Ellis), yang hendak memerangi pemikiran tidak rasional subjek yang dilayani dan mengubahnya menjadi pemikiran rasional.
10.Pendekatan Konseling Pancawaskita (Prayitno), yang menekankan pentingnya penggatraan gatra pada diri subjek yang dilayani. Gatra adalah sesuatu yang penuh arti; apa yang ada pada diri subjek yang dilayani, termasuk tingkah lakunya seharihari dibuat menjadi penuh arti.

Selain teori juga terdapat banyak teknikteknik dalam konseling individu baik teknik umum dan khusus, yang kesemuanya harus dikuasai oleh calon konselor. Karena dengan kemampuan memahami konsep teori dan teknik serta mampu memilih dan menerapkan teori dan teknik secara tepat sesuai karakteristik dan permasalahan koseli, dari situlah keterampilan konseling dapat diukur.

Untuk menuju keprofesionalan itu secara formal dipersiapkan di bangku pendidikan tinggi, salah satunya dengan menguasai konsep teori dan praktik bimbingan dan konseling, dalam hal ini teori dan teknik-teknik konseling individu. Pemahaman konsep teori dan teknik-teknik dalam pelayanan konseling individual oleh mahasiswa calon konselor adalah sangat penting dan mutlak.

Oleh sebab itulah peneliti ingin mengembangkan sebuah instrumen yang mencakup : a) pemahaman mahasiswa calon konselor pada konsep teori dan teknik konseling, b) pemahaman konsep dan sudah menggunakan teknik umum dan khusus konseling, c) ketepatan memilih suatu pendekatan teori dan teknik saat praktik konseling, d) ketepatan menggunakan suatu teori dan teknik yang dipilih secara benar,

\section{METODE PENELITIAN}

Penelitian menggunakan kuatitatif deskriptif dengan metode research and development. Research and development atau penelitian pengembangan dalam pendidikan, penelitian ini bertujuan untuk mengembangkan produk pendidikan berupa instrumen keterampilan dasar konseling untuk praktik layanan konseling individual. Oleh sebab itu penelitian pengembangan instrumen mengamati kevalidan dan kepraktisan dari alat ukur tersebut.

Instrumen penelitian yang digunakan adalah skala keterampilan dasar konseling yang akan dikembangkan oleh peneliti. Uji validitas akan menggunakan uji konstruk (construct validity) dan isi (content validity), dan uji reliabilitas dengan uji belah dua.

Uji konstruk dilakukan oleh dua dosen dengan kualifikasi bimbingan dan konseling, 
yaitu Hadi Pranoto, M.Pd. dan Retno Fajarwati, M.Pd. Uji validitas butir menggunakan rumus product moment, dari 40 butir item yang diuji, terdapat 6 butir yang tidak valid, yaitu no 5, 19,24, 27,31 dan 38. Uji reliabilitas instrumen menggunakan belah dua, dan diperoleh hasil reliabilitas 0,742 .

Teknik pengumpulan data meng-gunakan angket skala Keterampilan Dasar Konseling yang diberikan kepada seluruh mahasiswa subyek penelitian yang berjumlah 44 orang mahasiswa. Data yang telah diperoleh dianalisis dengan mendeskripsikan pemahaman konsep serta penguasaan teori dan teknik konseling oleh mahasiswa, dengaan metode yang digunakan nilai mean dan standar deviasi.

Pengujian analisis data dilakukan dengan meninjau dari pemahaman konsep dan penerapan teori serta teknik-teknik konseling saat praktik dengan beberapa aspek yaitu: (1)Tingkat pemahaman teori dan teknik-teknik konseling oleh mahasiswa BK, (2) Mahasiswa sudah menggunakan pendekatan teori dan teknik/belum saat praktik konseling. (3) Ketepatan mahasiswa dalam memilih suatu pendekatan teori konseling tertentu dalam praktik konseling. (4) Ketepatan mahasiswa dalam menggunakan teori dan teknikteknik konseling yang telah dipilih secara benar sesuai dengan karakteristik dan permasalahan konseli.

\section{HASIL DAN PEMBAHASAN}

Dapat dijelaskan, keterampilaan dasar konseling mahasiswa Program Studi Bimbingaan dan Konseling pada semester VI di UM Metro, masih tergolong sedang. Hal ini ditunjukkan dengan perolehan skor masing-masing indikator yakni pemahaman teori dan konsep konseling skor ideal yaitu 616, sedangkan perolehen skor total 382, pada indikator ; Sudah menggunakan pendekatan teori dan teknik konseling skor ideal adalah 264 sedangkan perolehsn skor total yaitu 166, kemudian dalam ketepatan memilih suatu pendekatan teori dan teknik konseling, diperoleh skor ideal yaitu 264 dan perolehan skor total responden sebesar 144, dan pada indikator menggunakan teori dan teknik konseling secara benar, diperoleh total skor sebesar 383 dari skor ideal 616.

Tabel 1. Rekapitulasi skor keterampilan dasar konseling mahasiswa BK UM Metro

\begin{tabular}{|c|c|c|c|c|}
\hline \multirow[b]{2}{*}{$\begin{array}{c}\text { Respon } \\
\text { Den }\end{array}$} & \multicolumn{4}{|c|}{ Indikator } \\
\hline & $\begin{array}{l}\text { Pemahaman } \\
\text { konsep teori dan } \\
\text { teknik-teknik } \\
\text { konseling }\end{array}$ & $\begin{array}{l}\text { Sudah } \\
\text { menggunakan } \\
\text { pendekatan teori } \\
\text { dan teknik }\end{array}$ & $\begin{array}{l}\text { Ketepatan } \\
\text { memilih suatu } \\
\text { pendekatan teori } \\
\text { dan teknik }\end{array}$ & $\begin{array}{l}\text { Menggunakan } \\
\text { teori dan teknik } \\
\text { konseling secara } \\
\text { benar }\end{array}$ \\
\hline No. & Skor & Skor & Skor & Skor \\
\hline 1 & 7 & 3 & 3 & 11 \\
\hline 2 & 8 & 4 & 5 & 10 \\
\hline 3 & 11 & 5 & 3 & 13 \\
\hline 4 & 9 & 5 & 4 & 10 \\
\hline 5 & 10 & 6 & 5 & 11 \\
\hline 6 & 8 & 4 & 3 & 6 \\
\hline 7 & 7 & 3 & 3 & 9 \\
\hline 8 & 8 & 6 & 2 & 5 \\
\hline 9 & 11 & 3 & 4 & 9 \\
\hline 10 & 11 & 3 & 3 & 6 \\
\hline 11 & 8 & 0 & 1 & 7 \\
\hline 12 & 9 & 4 & 4 & 7 \\
\hline 13 & 10 & 4 & 4 & 9 \\
\hline 14 & 8 & 1 & 4 & 9 \\
\hline 15 & 11 & 3 & 5 & 12 \\
\hline 16 & 6 & 5 & 4 & 9 \\
\hline 17 & 9 & 2 & 2 & 7 \\
\hline 18 & 12 & 4 & 4 & 8 \\
\hline 19 & 11 & 5 & 3 & 2 \\
\hline 20 & 7 & 3 & 3 & 8 \\
\hline 21 & 5 & 5 & 4 & 7 \\
\hline
\end{tabular}




\begin{tabular}{|c|c|c|c|c|}
\hline 22 & 5 & 4 & 4 & 8 \\
\hline 23 & 6 & 3 & 3 & 9 \\
\hline 24 & 11 & 4 & 3 & 8 \\
\hline 25 & 7 & 3 & 3 & 8 \\
\hline 26 & 12 & 4 & 3 & 9 \\
\hline 27 & 5 & 4 & 2 & 6 \\
\hline 28 & 9 & 5 & 1 & 9 \\
\hline 29 & 12 & 4 & 2 & 7 \\
\hline 30 & 11 & 4 & 2 & 11 \\
\hline 31 & 8 & 3 & 2 & 11 \\
\hline 32 & 9 & 5 & 3 & 12 \\
\hline 33 & 8 & 4 & 4 & 8 \\
\hline 34 & 7 & 2 & 4 & 7 \\
\hline 35 & 11 & 4 & 4 & 9 \\
\hline 36 & 12 & 4 & 3 & 10 \\
\hline 37 & 7 & 4 & 3 & 9 \\
\hline 38 & 9 & 4 & 3 & 11 \\
\hline 39 & 8 & 5 & 4 & 10 \\
\hline 40 & 6 & 3 & 5 & 8 \\
\hline 41 & 7 & 4 & 3 & 10 \\
\hline 42 & 8 & 3 & 3 & 9 \\
\hline 43 & 8 & 3 & 4 & 9 \\
\hline 44 & 10 & 5 & 3 & 10 \\
\hline Jumlah & 382 & 166 & 144 & 383 \\
\hline Ideal & 616 & 264 & 264 & 616 \\
\hline Kriteria & Sedang & Sedang & Sedang & Sedan \\
\hline
\end{tabular}

Berdasarkan tabel di atas dapat dijelaskan bahwa keterampilaan dasar konseling mahasiswa Program Studi Bimbingan dan Konseling pada semester VI di UM Metro, masih berada pada tingkatan sedang. Hal ini ditunjukkan dengan perolehan skor masingmasing indikator yakni pemahaman teori dan konsep konseling skor ideal yaitu 616, sedangkan perolehen skor total 382, pada sub variabel ; Sudah menggunakan pendekatan teori dan teknik konseling skor ideal adalah 264 sedangkan perolehsn skor total yaitu 166, kemudian dalam ketepatan memilih suatu pendekatan teori dan teknik konseling, diperoleh skor ideal yaitu 264 dan perolehan skor total responden sebesar 144, dan pada sub variabel menggunakan teori dan teknik konseling secara benar, diperoleh total skor sebesar 383 dari skor ideal 616.

Rangkuman dari keseluruhan indikator tersaji pada diagram di bawah ini: 


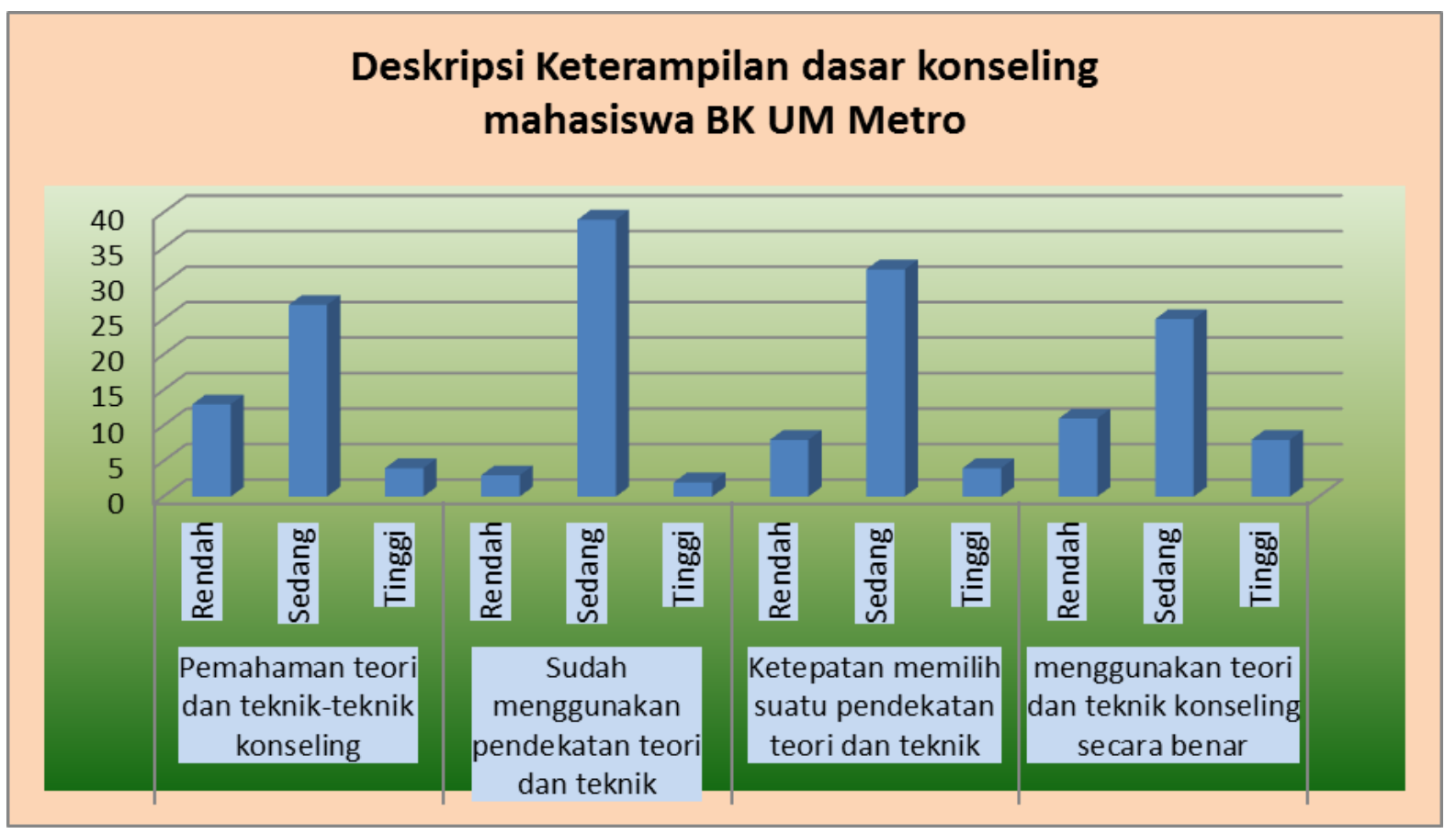

Gambar 1. Diagram keterampilan dasar konseling mahasiswa BK UM Metro

Diagram di atas menggambarakan bahwa pada empat indikator keterampilan konseling yang diteliti berada pada kategor sedang. Hal ini dapat ditarik kesimpulan bahwa mahasiswa BK UM Metro memiliki keterampilan dasar konseling secara umum berada pada kategori sedang.

\section{SIMPULAN DAN SARAN}

Kesimpulan penelitian Secara umum dapat digambarkan bahwa keterampilan dasar konseling mahasiswa BK UM Metro berada pada kategori sedang. Hal itu berdasarkan analisis data pada tiap -tiap indikator yang diteliti, seperti dibawah ini;

1. Pada indikator pemahaman teori dan teknik-teknik konseling berada pada kategori sedang

2. Indikator sudah menggunakan pendekatan teori dan teknik konseling mahasiswa BK UM Metro berada pada kategori sedang

3. Indikator ketepatan memilih suatu pendekatan teori dan teknik konseling berada ada kategori sedanf

4. Pada indikator Menggunakan teori dan teknik konseling secara benar mahasiswa
BK UM Metro berada pada kategori sedang.

Berdasarkan hasil yang telah diperoleh, maka dirumuskan saran penelitian yaitu (a) Perlu disusun sebuah panduan dalam praktikum konseling bagi mahasiswa BK. (b) Evaluasi keterampilan konseling hendaknya disusun secara spesifik dan mudah untuk digunakan agar menjadi acuan penilaian praktikum. (c) Dosen perlu memberikan kesempatan yang cukup bagi mahasiswa untuk melakukan simulasi dan praktikum konseling.

\section{DAFTAR PUSTAKA}

Ditjen Dikti. (2004). Dasar Standardisasi Profesi Konselor. Depdiknas.

Ida Umami.(2014). Bimbingan dan Konseling Dalam Pendidikan. Metro: STAIN Jurai Siwo

Mohamad Surya. (2009). Psikologi Konseling. Bandung : Maestro.

Namora Lumongga Lubis (2011). Memahami Dasar-dasar Konseling dalam Teori dan Praktik. Jakarta : Kencana Prenada Media Grup 
Prayitno. (2009). Wawasan Profesional Konseling. Padang: UNP Press.

Prayitno.(1998). Konseling Pancawaskita (Kerangka Konseling Eklektik). Program Bimbingan dan Konseling : FIP IKIP Padang.

Sofyan Willis, (2004). Konseling Individual Teori dan Praktek: ALFABETA

Syamsu Yusuf, L.N., dan A. Juntika

Nurihsan. (2012). Landasan

Bimbingan dan Konseling. Bandung : PT Remaja Rosdakarya.

Sugiyono. (2008). Metode Penelitian Pendidikan. Jakarta: ALFABETA.

Taufik. (2009). Model-model Konseling. Jurusan Bimbingan dan Konseling.FIP : UNP 